\author{
Aleksander Surdej \\ Katedra Studiów Europejskich \\ Uniwersytet Ekonomiczny w Krakowie \\ Krzysztof Wach \\ Katedra Przedsiębiorczości i Innowacji \\ Uniwersytet Ekonomiczny w Krakowie
}

\title{
Rola parków naukowo-technologicznych w rozwoju małych i średnich przedsiębiorstw
}

Najistotniejszym czynnikiem wpływającym na poziom innowacyjności przedsiębiorstw jest obecnie technologia (Raport o stanie ..., 2002, s. 223), która z kolei jest istotnym elementem składowym gospodarki opartej na wiedzy. Zastosowanie zaawansowanych technologii w małych i średnich przedsiębiorstwach pozwala na osiagnięcie przewagi konkurencyjnej na rynku. Nowe technologie rozwijane są zarówno przez laboratoria badawcze i laboratoria B+R (badania i rozwój) przedsiębiorstw, jak i przez publiczne ośrodki naukowe. Kluczową kwestiąjest współpraca środowiska naukowego z przedsiębiorcami; jej głównym celem powinien być transfer innowacji.

Celem niniejszego opracowania jest wyjaśnienie koncepcji transferu technologii z ośrodków naukowych do małych i średnich przedsiębiorstw na przykładzie parków naukowo-technologicznych.

Transfer technologii w najogólniejszym ujęciu jest przekazywaniem wiedzy $\mathrm{i}$ innowacyjnych idei z ośrodków tworzących wiedzę do jednostek wdrażających ją do produkcji, usług i innych rozwiązań gospodarczych. Efektem transferu technologii jest gospodarcza innowacja, czyli komercyjne zastosowanie nowych idei. Szybkość i efektywność wprowadzania innowacji stają się obecnie jednym z najważniejszych czynników sukcesu w konkurencji krajowej i międzynarodowej. Nawet jeśli dany kraj nie jest źródłem innowacji technologicznych, to nie jest obojętne, jak szybko przedsiębiorstwa uzyskują wiedzę o nowych technologiach i z jakim opóźnieniem ją stosują. Transfer technologii powinien być rozumiany jako integralna część procesu innowacji technologicznej, jako proces przemieszczania wyników badań naukowych lub opracowania inżynierskiego od twórcy do przedsiębiorcy. Jest to więc celowy proces komunikowania się i przekazywania (przejmowania) technologii, którego wynikiem powinien być wzrost wiedzy odbiorcy lub wzrost technicznego zaawansowania produktów, procesów produkcyjnych i zarządzania.

Transfer technologii jest to zatem przepływ wiedzy technicznej w różnych formach pomiędzy podmiotami. Oto formy tego przepływu (od najbardziej nieformalnych do najbardziej sformalizowanych/zinstytucjonalizowanych):

- wymiana idei w czasie seminariów, wykładów, pokazów, targów i wystaw handlowych;

- przepływy kadr (ludzi) pomiędzy ośrodkami tworzenia wiedzy a firmami, w tym przypadki czasowego zatrudnienia w innej firmie;

- zakup wyposażenia, patentów i licencji;

- bezpośrednie inwestycje zagraniczne (BIZ), joint venture, alianse strategiczne i umowy o pomoc techniczną (Donakowski 2003, s. 37 i 45). 


\section{Wpływ innowacyjności i transferu technologii na rozwój przedsiębiorstw}

Konkurencyjność firm to ,umiejętność sprostania konkurentom lokalnym regionalnym, krajowym i międzynarodowym” (Bednarczyk 2001, s. 15). Konkurencyjność w sektorze małych i średnich przedsiębiorstw jest to zatem umiejętność rywalizacji między tymi przedsiębiorstwami, mająca na celu zdobycie jak największej liczby klientów i osiagnnięcie jak największych korzyści z oferowanych usług i produktów. Przyszłe powodzenie przedsiębiorstwa zależy m.in. od pozycji, jaką zdobyło ono i utrzymuje na rynku. Przedsiębiorstwo ma potencjalne szanse na zdobycie przewagi konkurencyjnej dzięki dysponowaniu odpowiednimi zasobami i kompetencjami w przewidywaniu i dostosowywaniu się do zmian rynkowych oraz zdolnościami menedżerskimi (zarządzania zmianami). Wszystkie działania mające na celu uzyskanie przewagi konkurencyjnej docenianej przez klientów zmierzają do jednego - wygrania w walce konkurencyjnej (Strategor 1999, s. 68). Pozycja konkurencyjna danego przedsiębiorstwa jest wypadkową jego siły i słabości. Zależy ona od stopnia wykorzystania kluczowych czynników sukcesu. W literaturze z zakresu zarządzania wyróżnia się trzy krytyczne czynniki decydujące o efektywności zarządzania konkurencyjnością. Są to (Bednarczyk 2001, s. 30):

- myślenie strategiczne, opracowanie i realizacja efektywnych strategii;

- innowacje i przedsiębiorczość wewnętrzna;

- zastosowanie zaawansowanych technologii informacyjnych.

Myślenie strategiczne w przedsiębiorstwie polega na wybiegającym w przyszłość, wielokierunkowym i interdyscyplinarnym podejściu do zarządzania. Strategiczne podejście do zarządzania wymaga analizy i wyboru spośród szerokiej gamy metod, środków i sposobów działania przedsiębiorstwa, tak aby zapewnić maksymalne wykorzystanie możliwości i szans (Penc-Pietrzak 1998, s. 11). Z drugiej strony, zarządzanie strategiczne jest to zarządzanie ciągłym procesem zmian i rozwoju przedsiębiorstwa, z uwzględnieniem wzajemnych powiązań przedsiębiorstwa z jego otoczeniem, a zwłaszcza potencjału, jaki stwarza współpraca w zakresie transferu zaawansowanych technologii. Zaawansowane technologie, w tym technologie informacyjne, sprzyjają bowiem wzrostowi konkurencyjności w warunkach „nowej ekonomii”. Są szansą na osiagnięcie przewagi konkurencyjnej przez stosujące je przedsiębiorstwa oraz na stworzenie nowej oferty usług i/lub produktów dla klientów, prowadzą do nowych form współpracy pomiędzy przedsiębiorstwami, a także zmieniają zachowanie klientów.

Procesy globalizacyjne w gospodarce światowej oraz intensywny rozwój technologii komunikacyjno-informacyjnej wywierają zasadniczy wpływ na strategię konkurowania przedsiębiorstw. „Coraz częściej sukces przedsiębiorstwa zależy od percepcji i wykorzystania szans tkwiących w otoczeniu komunikacyjnym, które stało się multimedialne" (Bednarczyk 1999, s. 239).

W okresie globalizacji gospodarki dla rozwoju przedsiębiorstw istotny jest postęp technologiczny. Nowe idee, pomysły i innowacje będące źródłem rozwoju technologii to jednak nie wszystko. Niezwykle istotną kwestią jest komercjalizacja osiagnięć naukowo-technicznych, czyli transfer tych osiagnięć na rynek. Polega on na przekazywaniu wiedzy technicznej i organizatorskiej w celu wykorzystania jej dla celów gospodarczych (Wach 2008). Jest on naturalnym źródłem rozwoju innowacyjnych firm. Niewystarczające zasoby finansowe oraz potencjał kadrowy mikro-, małych i średnich przedsiębiorstw są trudną do przezwyciężenia barierą do podjęcia własnych badań przez firmy małe i średnie. Pomocą w rozwiązaniu tego problemu może być podjęcie współpracy przedsiębiorstw z uczelniami, zwłaszcza technicznymi, oraz państwowymi lub komercyjnymi placówkami badawczymi. Przykładem działań wspierających transfer wiedzy i technologii są parki technologiczne, centra innowacji oraz ,skupiska” przedsiębiorstw (klastery, grona). Są one pożądane zwłaszcza w wypadku małych i średnich firm innowacyjnych. 
Współpraca przedsiębiorców sektora małych i średnich przedsiębiorstw z ośrodkami naukowo-badawczymi dotyczy głównie kwestii związanych bezpośrednio z procesem produkcyjnym. Rzadziej współpraca dotyczy tzw. usług okołoprodukcyjnych, do których zalicza się m.in. badanie rynku i działania marketingowe. Według badań Ipson-Demoskop, głównymi motywami współpracy sektora MSP ze sferą B+R są (Raport o stanie ..., 2002, s. 231-234):

- chęć uzyskania poprawy jakości produktów i usług,

- rozwój firmy,

- obniżenie kosztów,

- przeciwdziałanie konkurencji,

- utrzymanie się na rynku,

- dostęp do informacji - rozpoznanie rynku,

- wymogi prawne (głównie uzyskanie potrzebnych certyfikatów).

Wśród głównych barier współpracy MSP ze sferą B+R przedsiębiorcy wskazują niedostosowanie oferty placówek naukowo-badawczych do ich potrzeb. Według przedsiębiorców, ośrodki naukowo-badawcze nie są przygotowane do współpracy ze środowiskiem biznesowym. Sytuacja wygląda stosunkowo najlepiej w sferze nauk ekonomicznych, gdzie współpraca jest dwutorowa: ośrodki naukowe (głównie uczelnie) oferują przedsiębiorcom możliwość korzystania z sympozjów, konferencji, szkoleń, studiów doktoranckich; z drugiej zaś strony istnieje możliwość udostępnienia danych na potrzeby badań naukowych, w celu weryfikacji strategii działania przedsiębiorstw.

\section{Park technologiczny jako instytucja wspierająca transfer innowacji}

Jedną z szybko rozpowszechniających się instytucjonalnych form wspierania transferu technologii są parki technologiczne (funkcjonują one na świecie pod wieloma nazwami: parki biznesowe, cyberparki, hi-tech parki, parki przemysłowe, centra innowacji, parki badawcze, parki naukowe, centra naukowe, inkubatory technologii, technoparki, technopole). Na początku XXI w. na całym świecie istniało ponad 400 parków technologicznych, przy czym około jednej trzeciej z nich w Stanach Zjednoczonych.

Parki technologiczne tworzy się w celu przyspieszenia powstawania i rozwoju firm innowacyjnych, poprzez zapewnianie środowiska, które umożliwia firmom rozwijanie relacji z centrami tworzenia wiedzy i innowacji, promowanie formalnych i operacyjnych więzi z uniwersytetami i instytucjami badawczymi. Parki technologiczne ułatwiają dostęp do niezbędnego ludzkiego i fizycznego kapitału dla nowych firm wykorzystujących zaawansowane technologie, kreują także środowisko sprzyjające transferowi technologii oraz umiejętnościom biznesowym.

Parki technologiczne wydają się szczególnie efektywną instytucjonalną formą wspierania konkurencyjności małych i średnich przedsiębiorstw. Wśród głównych celów parku technologicznego jako instytucji wspierającej rozwój drobnych, małych i średnich przedsiębiorstw w regionie należy wymienić:

- wspieranie zakładania nowych firm,

- przyciaganie kapitału z zewnątrz,

- wspieranie rozwoju firm istniejących w regionie,

- rozwój innowacji i przedsiębiorczości,

- transfer najnowszych osiągnięć naukowych do firm. 
Zgodnie z definicją Unii Europejskiej, park technologiczny (park naukowy) to przedsięwzięcie rozwojowe na terenie znajdującym się w pobliżu jednej lub kilku uczelni wyższych, a także centrów badawczych, lub który ma z tymi instytucjami wygodne i działające połączenia. Firmy, które wprowadzają się na teren parku, czynią to zwykle zachęcone bliskością uniwersytetu lub centrum naukowego, ale i atrakcyjnością lokalizacji. Park technologiczny jest również definiowany jako zainicjowany oraz subwencjonowany ze środków publicznych zorganizowany ośrodek gospodarczy, w ramach którego tworzy się dogodne warunki do powstawania i rozwoju małych innowacyjnych firm (Matusiak 1995, s. 5). Parki technologiczne zarządzane są przez wysoko wykwalifikowaną kadrę, której celem jest promowanie innowacji oraz wspieranie firm działających w obrębie parku. Główną funkcją parku technologicznego jest transfer wiedzy oraz innowacji z instytucji rozwijających technologię do firm. Park technologiczny ma na celu:

- wspieranie tworzenia i rozwoju tych przedsiębiorstw, które opierają się na zdobyczach nauki (knowledge-based firms);

- ułatwianie transferu technologii z lokalnych ośrodków badawczych i akademickich do firm i organizacji działających w parku lub poza nim;

- zapewnienie odpowiednich warunków przestrzennych dla kooperacji środowisk naukowych oraz firm innowacyjnych.

W strukturze organizacyjnej parku technologicznego występują cztery elementy (Kasperkiewicz 1997, s. 27):

- infrastruktura parku (budynki, wspólne urządzenia serwisowe, baza socjalna i sieć firm usługowych);

- centrum kierowania parkiem (zarząd parku, rada nadzorcza, ciała doradcze, eksperci);

- potencjał technologiczny będący rdzeniem parku (m.in. publiczne ośrodki badawcze, uczelnie, działy badawcze przedsiębiorstw);

- grupa małych i średnich przedsiębiorstw innowacyjnych, które specjalizują się w szybkim opanowywaniu zaawansowanych technologii.

W parku technologicznym rozwijają działalność głównie małe i średnie firmy innowacyjne; mogą w nich być również zlokalizowane laboratoria badawcze dużych przedsiębiorstw. Na całym świecie potencjał technologiczny publicznych (państwowych, zarówno centralnych, jak i regionalnych) ośrodków naukowych stanowi znaczący element otoczenia rynkowego, jest jego ważnym zasobem. Ów zasób powinien być rozumiany nie tylko statycznie, jako coś, co istnieje i jest zastane, ale także dynamicznie, jako owoc rozwoju, skutek wewnętrznej dynamiki środowiska.

Zasoby, jakimi są pomysły, innowacje i rozwój technologii, powinny być umiejętnie używane. Niezwykle istotną kwestiąjest komercjalizacja osiągnięć naukowo-technicznych, czyli transfer tych osiagnięć na rynek, który polega na przekazywaniu wiedzy technicznej i organizatorskiej w celu wykorzystania jej do celów gospodarczych. W ramach silnego centrum uniwersyteckiego kreuje się nowe kierunki poszukiwania rozwiązań naukowych, gromadzona jest wiedza, kreowane są nowe wynalazki. Stanowi to z kolei naturalne źródło rozwoju innowacyjnych firm. Szkoły wyższe zapewniają również wysoko wykwalifikowaną kadrę oraz potencjalnych przedsiębiorców. Niewystarczające zasoby finansowe oraz potencjał kadrowy drobnych, małych i średnich przedsiębiorstw są uzupełniane poprzez czerpanie zasobów ze środowiska. Służy temu współpraca przedsiębiorstw z uczelniami oraz państwowymi placówkami badawczymi.

Park technologiczny stwarza możliwość stałej i ścisłej kooperacji przedsiębiorców z naukowcami. 
Tab. 1. Siedem cech klasycznego parku technologicznego

1. Ekonomiczna efektywność (minimum 3 tys. $\mathrm{m}^{2}$ powierzchni użytkowej oraz 15-20 firm).

2. Spółka $z$ ograniczoną odpowiedzialnością jako forma prawna (dopuszcza się również fundację, zakład budżetowy gminy oraz spółkę cywilną).

3 Podział na dwie części:

a) inkubatory przedsiębiorczości i centra technologiczne, które oferują gotowe pomieszczenia oraz budynki;

b) parki nauki wydzierżawiające parcele do własnego zagospodarowania.

4. Infrastruktura parku obejmuje: budynki, wspólne urządzenia serwisowe, bazę socjalną i sieć firm usługowych.

5. Parkiem zarządza specjalna jednostka, w której skład mogą wchodzić: zarząd parku, rada nadzorcza, ciała doradcze, eksperci.

6. Dysponowanie potencjałem technologicznym (publiczne ośrodki badawcze, wyższe uczelnie, działy badawcze firm).

7. Obecność grupy małych i średnich przedsiębiorstw innowacyjnych (specjalizujących się w szybkim opanowywaniu nowych technologii).

Źródło: Sieja, Tomczyk, Wach, s. 483.

Tworzenie parków technologicznych oczywiście nie prowadzi automatycznie do przyspieszenia transferu technologii. Zawsze istnieje niebezpieczeństwo niskiej jakości współpracy pomiędzy lokalnym środowiskiem naukowym a firmami działającymi w obrębie parku. Tak wydaje się być w niektórych państwach UE. Może o tym świadczyć fakt, że 57\% firm belgijskich oraz 32\% firm holenderskich prowadzi własne prace badawczo-rozwojowe, przy jednoczesnej niskiej ocenie współpracy z uczelniami (Dierdonck, Debackere, Rappa 1991, s. 109-122). Podobna sytuacja panuje w firmach zlokalizowanych w parkach nauki w Wielkiej Brytanii, Kanadzie i Australii. Ponad 70\% firm działających w Cambridge Science Park informowało o braku powiązań ze światem nauki lub ich niewielkim praktycznym znaczeniu (Baruk 2001). W niektórych wypadkach także w Stanach Zjednoczonych współpraca firm działających w parkach technologicznych z uniwersytetami ogranicza się do rekrutacji absolwentów oraz wykorzystywania uniwersyteckiego sprzętu i urządzeń.

Problem transferu technologii powinien być rozwiązywany z uwzględnieniem lokalnego kontekstu i historycznych doświadczeń. W regionie krakowskim powstało wiele powiązań środowiska naukowego z przedsiębiorcami, które ze względu na charakter wzajemnych relacji moga zostać określone mianem klastera (Morawczyński, Rogoda 2005). Klaster to geograficzne skupisko konkurujących i współpracujących ze sobą firm, wyspecjalizowanych dostawców, ośrodków naukowych oraz jednostek świadczących usługi (Porter 2001, s. 246). Klaster krakowski bazuje na zaawansowanych technologiach oraz transferze innowacji ze środowiska naukowego do przedsiębiorstw. Transfer nowych technologii może odbywać się trzema „kanałami”. Podstawową formą współpracy nauki i biznesu są parki technologiczne. Inną formą promowania nowych technologii jest zakładanie firm przez pracowników naukowych, co pozwala na komercjalizację wiedzy. Dobrym przykładem może być rozwój firmy ComArch, założonej przez pracownika naukowego Akademii Górniczo-Hutniczej. Jeszcze innym sposobem promowania nowych technologii jest wspieranie transferu innowacji przez pomoc w pozyskiwaniu środków finansowych z funduszy zagranicznych. Dobrym przykładem może być Centrum Transferu Technologii Politechniki Krakowskiej. 


\section{Konkluzje}

Współczesne państwa konkurują o technologiczne przodownictwo, a także o przyciaganie naukowych i biznesowych talentów. Kraj, który znacznie odstaje od krajów przodujących w zakresie rozwoju i stosowania technologii, nie tylko nie przyciąga technologii i talentów, ale traci kapitał ludzki, gdyż jego obywatele zaczynają szukać gdzie indziej możliwości naukowej, biznesowej czy ludzkiej samorealizacji.

Konkurencja jest faktem. Znalezienie skutecznego sposobu sprostania konkurencji międzynarodowej jest wyzwaniem. Państwa poszukują swoich własnych sposobów poprawy pozycji konkurencyjnej, obserwując doświadczenia innych, czerpiąc z nich i modyfikując je. Analiza doświadczeń państw Europy Zachodniej i Stanów Zjednoczonych wskazuje, że parki technologiczne mogą być, lecz wcale nie musza, czynnikiem przyspieszenia produkcji i transferu wiedzy. Wprawdzie formy instytucjonalne są ważne, ale równie ważne jest tworzenie innowacyjnego środowiska, stymulującej atmosfery badawczej i twórczej rywalizacji. Badania pokazują że istotnym czynnikiem sprzyjającym produkcji i transferowi wiedzy jest jakość relacji pomiędzy ośrodkami naukowymi a biznesem, gdyż bliskość i intensywność relacji nauka - gospodarka pobudza i ukierunkowuje rozwój badań o zastosowaniu przemysłowym, owocuje dynamicznym wzrostem wiedzy i jej gospodarczych zastosowań, niezależnie od instytucjonalnych form, w jakich te relacje przebiegaja (Westhead i Storey 1995).

\section{Literatura}

1. Baruk J., Centra przedsiębiorczości a innowacyjność firm, „Organizacja i Kierowanie”, 2/2001.

2. Bednarczyk M., 1999, Wptyw otoczenia komunikacyjnego na redefinicje strategii konkurencji polskich przedsiębiorstw [w:] Konkurencyjność przedsiębiorstw wobec wyzwań XXI wieku, Wyd. AE we Wrocławiu, Wrocław.

3. Bednarczyk M., 2001, Organizacje publiczne. Zarzadzanie konkurencyjnościa, PWN, Kraków-Warszawa.

4. Dierdonck R. van, Debackere K., Rappa M.A., An Assessment of Science Parks: Towards a Better Understanding of Their Role in the Diffusion of Technological Knowledge, "R\&D Management", 2/1991.

5. Donakowski A., Międzynarodowy transfer technologii- przyczyny, formy i konsekwencje, „Gospodarka w praktyce i teorii", 1/2003.

6. Kasperkiewicz W., 1997, Parki technologiczne nowoczesna forma promowania innowacji, Wyd. Absolwent, Łódź.

7. Matusiak K.B., 1995, Parki technologiczne. Instytucjonalne wspieranie przedsiębiorczości, procesów innowacyjnych rozwoju regionalnego, Fundacja Inkubator, Łódź.

8. Morawczyński R., Rogoda B., Rola środowiska naukowego w promowaniu nowych technologii na przykładzie Krakowa, „Zeszyty Naukowe”, 62/2003, „Prace z zakresu przedsiębiorczości i konkurencyjności firm", Wyd. AE w Krakowie, Kraków.

9. Penc-Pietrzak I., 1998, Strategia biznesu i marketingu, Wyd. PSB, Kraków.

10. Porter M.E., 2001, Porter o konkurencji, PWE, Warszawa.

11. Raport o stanie sektora matych i średnich przedsiębiorstw $w$ Polsce $w$ latach 2000-2001, PARP, Warszawa 2002.

12. Sieja M., Tomczyk K., Wach K., 2002, Rola Krakowskiego Parku Technologicznego w transferze innowacji [w:] Handel międzynarodowy 2002. Stan i kierunki rozwoju, K. Budzowski, S. Wydymus (red.), KHZ AE w Krakowie, Kraków.

13. Strategor, 1999, Zarzadzanie firma, PWE. 
14. Wach K., Wspótpraca małych i średnich przedsiębiorstw z ośrodkami naukowo-badawczymi na przykładzie Krakowskiego Parku Technologicznego, „Zeszyty Naukowe”, 671/2005, „Prace z zakresu przedsiębiorczości i innowacji”, Wyd. AE w Krakowie, Kraków.

15. Wach K., 2008, Regionalne otoczenie matych i średnich przedsiębiorstw, Wyd. UEK, Kraków 2008.

16. Westhead P., Storey D. J., Links Between High Education Institutions and High Technology Firms, Omega, Vol. 23, No 4/1995.

\section{The Role of Science-technological Parks in the Development of Small and Middle Enterprises}

In the globalization era a technological growth is important for the development of the companies. The vital challenge is a commercialization of the science and technological achievements, i.e. transfer the achievements to the market. The transfer consists of passing on the technological and managerial knowledge to be used in business. It is natural impulse for the development of innovational companies. Insufficient financial and human resources in small and middle enterprises set the difficult to conquer barrier to conducting in-home research. The cooperation between companies and universities - especially engineering schools and public or commercial research centers - may help to resolve the problem. The aim of this article is the presentation of the role of science-technological parks in the development of small and middle enterprises. 